\title{
HEALTH STIMULATING PROPERTIES OF THE MOST POPULAR SOFT CHEESE IN EGYPT KARIESH MADE USING SKIMMED MILK UF-RETENTATE AND PROBIOTICS
}

\author{
A.E. Fayed ${ }^{1 \bowtie}$, Azza M. Farahat ${ }^{1}$, A.E. Metwally ${ }^{1}$, M.S. Massoud ${ }^{2}$, A.O. Emam ${ }^{1}$ \\ ${ }^{1}$ Food Science Department, Faculty of Agriculture, Ain Shams University, Cairo, Egypt \\ ${ }^{2}$ Regional Center for Food and Feed, Agriculture Research Center, Giza, Egypt
}

\begin{abstract}
Background. Soft skimmed-milk cheese Kariesh is the most popular soft cheese in Egypt. In the past, Karish cheese was traditionally produced by the random fermentation of milk speared its cream layer by the gravity force. Recently, its production has been carried out by several manufacturing procedures using, ultrafiltration (UF) - skimmed milk retentate, certain bacterial cultures, enzymatic coagulation, etc. Therefore, the biological and nutritional evaluations are required. The present study was conducted to evaluate the properties of such cheese coagulated using different procedures involving probiotic strains with emphasis on some chemical and biological attributes.

Material and methods. Kariesh cheeses were manufactured without whey drainage from UF cow's skimmed milk concentrate coagulated either by $3 \%$ yoghurt bacterial starter culture (YC), 3\% probiotic starter culture (ABT type) or $2.5 \%$ glucono delta lactone (GDL) added whether separately or incorporated with rennet $(0.05$ $\mathrm{ml} / \mathrm{kg}$ ) to achieve the acidic-enzymatic coagulation in comparison with those made conventionally using un-concentrated milk coagulated either by $2 \%$ of YC or ABT added whether separately or incorporated with rennet $(0.25 \mathrm{ml} / \mathrm{kg})$. Due to the fact that whey is naturally needed to drain in the conventional $(\mathrm{C})$ procedure, the use of GDL as coagulant was eliminated.

Results. The obtained results indicated that the application of UF-technique in Kariesh cheese industry was associated with significant increments in the values of protein, ash and $\mathrm{pH}$. Moreover, the electrophoretical patterns of UF-Kariesh cheese obtained with the incorporation between YC, ABT or GDL and rennet were distinguished with the presence of the band of glycomacropeptide, which is normally lost in the whey through the C-procedure. Furthermore, the food intake (FI), body weight gain (BWG), food efficiency ratio (FER), triglycerides (TG), total cholesterol (TC), high density lipoproteins (HDL), total, as well as ionized Ca of blood and the count of lactic acid bacteria of feces of rats were significantly heightened, while low density lipoprotein (LDL) level was lowered as they fed on UF-cheeses, especially when coagulated using ABT, those caused the strongest persistence against the rat colon tumor, which was induced by the injection with 1,2 di-methyl hydrazine. The use of ABT led to raise the dry matter (DM) and ash of Kariesh cheese. Also, the FI, BWG, FER, TG, total, as well as ionized Ca of blood and the count of lactic acid bacteria of feces of rats were significantly increased, while TC, HDL and LDL of blood, as well as coliform count of feces of rats were significantly declined. The incorporation of enzymatic with acidic coagulation in Kariesh cheese manufacture increased significantly the values of ash and $\mathrm{pH}$. However, the cheese figures of DM, protein and titratable acidity were decreased. Also, the values of FI, BWG, FER, TC, HDL, LDL and feces LAB of rats were lowered. Whilst, the values of TG, total as well as ionized $\mathrm{Ca}$ and feces coliform of rats were increased.
\end{abstract}

Key words: electrophoresis, in vivo, blood serum, colon anatomy

凶profateffayed@yahoo.com 


\section{INTRODUCTION}

Skimmed milk (Kariesh) cheese is one of the indigenous white soft cheese types in Egypt. Kariesh, as well as Domiati chesses are the most popular varieties of soft cheese in Egypt, but the former is the oldest type manufactured since 3000 B.C. It is composed of about $50 \%$ of white soft cheeses produced in Egypt [Abou-Donia 1991, Hegazy et al. 2012].

In the past traditional $(\mathrm{T})$ Kariesh cheese was made on the farms from 'Rayeb' milk. The latter is a naturally developed acidity coagulant during gravity creaming in earthenware containers. After skimming the sour cream, the 'Rayeb' milk is drained in folded mats. Draining of the whey takes two or three days, or until the desired texture of cheese is obtained. Finally, cheese is cut into suitable pieces, then dry salted to taste. The salted cheese is left for a few more hours in the mat until no more whey drains out and is then ready to be consumed as fresh cheese. Resultant cheese is either consumed fresh or after pickling in available farm-house milk by-products, e.g. butter milk, 'Murta', whey... etc. [Fayed 1986]. The quality and composition of T-Kariesh cheese may vary considerably due to such factors as: the quality and composition of the clotted skim milk, the method of manufacture, the time required to complete the drainage of whey, the quality of salt added and the method of handling the finished cheese [Fahmi 1950, El-Gendy 1983, Abou-Donia 1984, 1991, 1995, 1999 a, b, 2008].

Recently, where centrifugal separators are used, this cheese is conventionally produced by acid coagulation of mechanically skimmed milk by culturing with lactic acid bacteria. Skimmed milk results in inferior Kariesh cheese type due to lower fat content in separator's skimmed milk. Because of its low fat content, it has a firm brick-like texture that is undesirable to many consumers. The firm texture of low fat cheese is due to the high density of the protein network, which results from the absence of fat globules that normally act as fillers in the structural network. Producing cheese with a more open structure could be one means of controlling excessive firmness in this cheese [Fayed 1986, Hassan et al. 2004]. Therefore, several approaches have been proposed to improve the quality, safety and productivity of Kariesh cheese involving solids enrichment by skimmed milk powder
[Youssef et al. 1981], heat treatment of milk [Fahmi 1950, El-Sadek and Abd El-Motaleb 1958 a, b, Abdou and Dawood 1977, Abou-Dawood and Gomai 1977], certain bacterial starter addition [Abd El-Salam et al. 1984, El-Shibiny et al. 1984], enzymatic coagulating, direct acidification [Hamdy and Sayed 1971, Wahba and El-Abbassy 1982, Hofi et al. 2004] and ultrafiltration concentration of milk [Abd El-Salam et al. 1984, El-Shibiny et al. 1984, Fayed 1986, Hofi et al. 1986, Mahran et al. 1986, El-Zayat and Omar 1987, Renner and Abd El-Salam 1991, Hofi et al. 2004].

Given the growing awareness of the health of the consumer, Kariesh cheese becomes very popular because of its remarkable health quality as the only known relatively fat free cheese consumed by the Egyptians. It is often recommended for persons suffering from obesity, cholesterol and heart disease.

Nevertheless, most of the foregoing improving attempts lacked to cover some necessary attributes of the resultant product, especially those aimed to be enhanced such as the nutritional and biological properties. For that in view, the present study was conducted to evaluate the properties of such cheese coagulated using different procedures involving probiotic strains with emphasis on some chemical and biological attributes.

\section{MATERIAL AND METHODS}

\section{Materials}

Fresh cow's skimmed milk was obtained from the herd of the armed forces farms in Cairo-Ismailia desert road (TS $8.8 \%, 0.2$ fat, 3.6\% protein and $\mathrm{pH} 6.7$ ). Skimmed milk powder was obtained from Synlait Milk Ltd., Rakaia 7783 - New Zealand (3.8\% moisture, $34 \%$ protein, $1.5 \%$ fat and $8.3 \%$ ash).

Dried microbial rennet was obtained from MAYSA GIDA San ve Tic. A.S., Tuzla Kimya Sanayicileri Organize Sanayi Bolgesi Melek Aras Bulvari No:54 TUZLA, Istanbul, 34956, Turkey.

Concentrated lyophilized probiotic bacterial strains (ABT-5) containing Lactobacillus acidophilus La-5, Bifidobacterium BB-12 and Streptococcus thermophilus, as well as concentrated lyophilized mixed yoghurt starter culture (YC-183) contains Str. thermophilus and Lb. delbrueckii ssp. bulgaricus, 1:1, were obtained from Chr. Hansen Lab., Denmark. 
Fayed A.E., Farahat A.M., Metwally A.E., Massoud M.S., Emam A.Q., 2014. Health stimulating properties of the most popular soft cheese in Egypt Kariesh made using skimmed milk UF-retentate and probiotics. Acta Sci. Pol., Technol. Aliment. 13(4), 359-373.

Glucono delta lactone (GDL) was obtained from Shandong Kaison Biochemical Co., LTD, Wulian Country, Shandong China.

Sodium chloride $(\mathrm{NaCl})$ was obtained from El-Nasr for Salt Production Co. Potassium sorbate was obtained from SJZ Chem-Pharm Co., Ltd. China.

\section{Manufacturing procedures of Kariesh cheese}

Conventional Kariesh cheese. Skimmed cow's milk was enriched with skimmed milk powder to

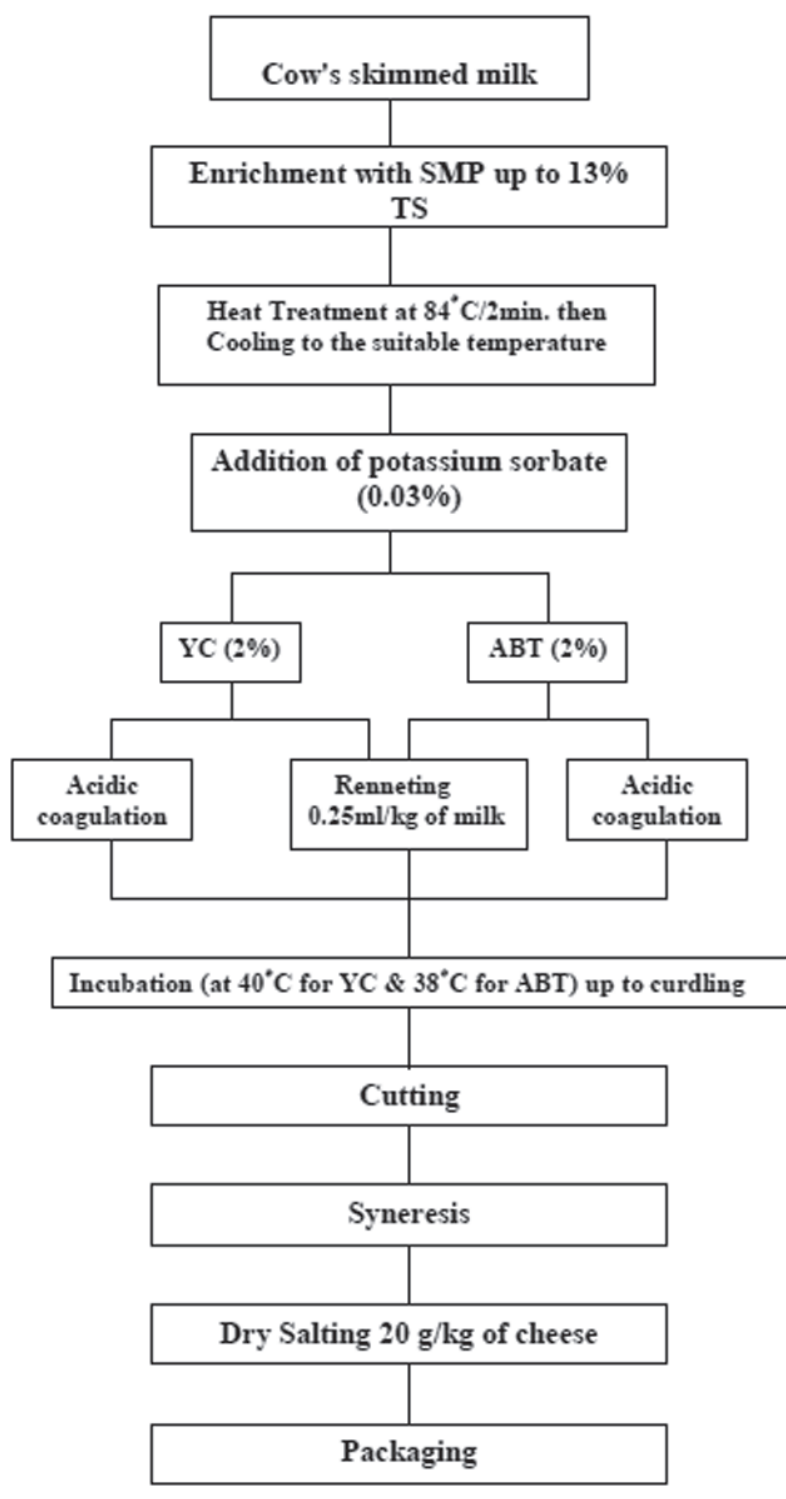

Fig. 1. Flow diagram of conventional Kriesh cheese making
$13 \%$ total solids, heated at $84^{\circ} \mathrm{C}$ for $2 \mathrm{~min}$, cooled to the suitable temperature, $0.03 \%$ potassium sorbate was added, and then divided into 4 equal portions. The 1st portion (control) was inoculated with $2 \%$ of freshly activated YC starter culture and incubated at $40^{\circ} \mathrm{C}$ up to curdling. The 2 nd portion was inoculated with freshly activated $2 \%$ ABT starter culture and incubated at $38^{\circ} \mathrm{C}$ up to curdling. The 3 rd portion was inoculated with $2 \% \mathrm{YC}$ starter culture $+0.25 \mathrm{ml}$ rennet solution $(4 \%) / \mathrm{kg}$ milk and incubated at $40^{\circ} \mathrm{C}$ up to curdling. While the 4th portion was inoculated with $2 \%$ activated $\mathrm{ABT}$ starter culture + rennet (at the forgoing level) and incubated at $38^{\circ} \mathrm{C}$ up to curdling. The curds were cut and filled into stainless steel moulds lined with cheese cloth and consolidated by a slight

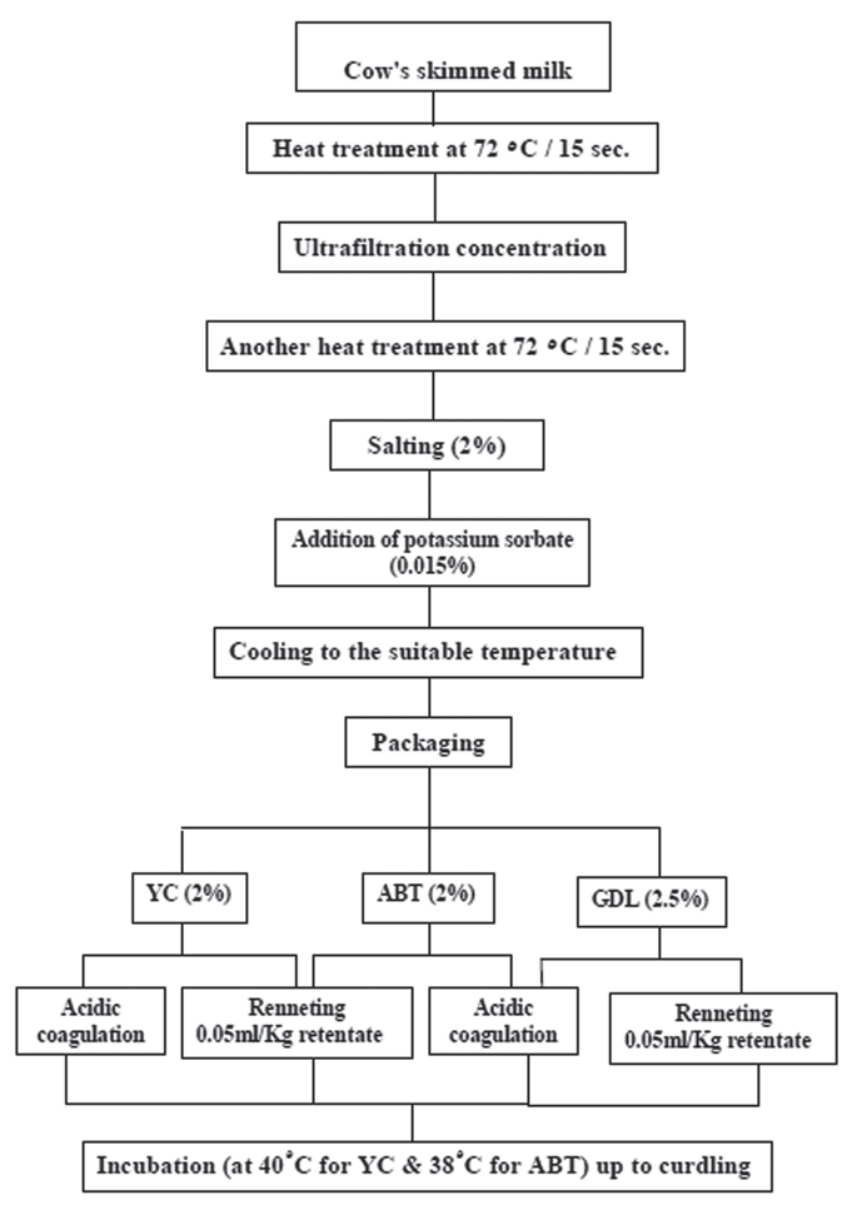

Fig. 2. Flow diagram of ultrafiltrated Kariesh cheese manufacturing 
pressure for $24 \mathrm{~h}$. The blocks of curd were then cut, dry salted using $\mathrm{NaCl}(2 \% \mathrm{w} / \mathrm{w})$ and packaged into plastic containers (Fig. 1).

Ultrafiltrated Kariesh cheese. Skimmed cow's milk was firstly heat treated at $72^{\circ} \mathrm{C}$ for $15 \mathrm{~s}$, cooled immediately to $5^{\circ} \mathrm{C}$ and re-warmed to $50^{\circ} \mathrm{C}$ at which the UF-process was run as recommended by Maubois et al. [1987] using UF TECH-SEP (group of Rhone Poulenc) unit equipped with Carbo Sep tubular mineral membrane having area $34.2 \mathrm{~m}^{2}$ and a nominal molecular weight cut off $20 \mathrm{KDa}$. The resultant retentate (concentrated to give the milk solids content desired in the final Kariesh cheese) was subjected to another heat treatment $\left(72^{\circ} \mathrm{C} / 15 \mathrm{~s}\right)$, cooled to the suitable temperature, salted using $\mathrm{NaCl}(2 \% \mathrm{w} / \mathrm{w})$ and $0.015 \%$ potassium sorbate then divided into 6 equal portions and filled into plastic containers. The 1 st and 2 nd portions were inoculated with an activated $\mathrm{YC}$ starter culture or ABT starter culture at the level of 3\% instead of $2 \%$ (to avoid the relatively reduced water activity of concentrated milk as recommended by Fayed [1986] and incubated at 40 or $38^{\circ} \mathrm{C}$, resp. up to curdling. The 3 rd portion was inoculated with $3 \%$ activated YC starter culture $+0.05 \mathrm{ml}$ rennet solution $(4 \%) / 1 \mathrm{~kg}$ retentate and incubated at $40^{\circ} \mathrm{C}$ up to curdling. The 4th portion was inoculated with $3 \%$ activated ABT starter culture + rennet (at the forgoing level) and incubated at $38^{\circ} \mathrm{C}$ up to curdling. The 5 th portion was coagulated by $2.5 \%$ GDL at room temperature. While the 6th portion was coagulated by $2.5 \% \mathrm{GDL}+$ rennet (at the forgoing level) at $40^{\circ} \mathrm{C}$ (Fig. 2).

For the biological study, fresh cheese samples were dried in an oven at $50^{\circ} \mathrm{C}$ for $24 \mathrm{~h}$ as described by Fayed et al. [2011 a, b].

\section{Analytical methods}

Dry matter, fat, total nitrogen and ash contents as well as titratable acidity (TA) \% were determined according to AOAC [2007]. While the salt content was determined in cheese according to the method of Vanderburg as described by Kotterer and Munch [1978].

The $\mathrm{pH}$ values were measured using a microprocessor pH meter (model 8417, Hanna Instruments, Singapore) at $20^{\circ} \mathrm{C}$ after calibrating with fresh $\mathrm{pH} 4.0$ and 7.0 standard buffer solutions.
For the electrophoretical fractionation of cheese protein, the method of Weber and Osborn [1969] was applied for protein extraction. Sodium dodecyl sulfate polyacrylamide gel electrophoresis (SDS-PAGE) was preformed according to the method of Laemmli [1970] as modified by Studier [1973]. The SDS-PAGE patterns of milk proteins were identified according to Basch et al. [1985], Farrell et al. [2004] and Gab-Allah [2011].

The biological experiments were carried out using standardized 48 white male albino rats with the initial body weights ranging from 100-170 $\mathrm{g}$ and their age at the start of the study was 7 weeks. The animals were housed in individual metabolic cages; those were employed for rats, comprised an upper living area with feeding system and below a device for the collection of urine and feces. The cages were similar in construction to those described by Schiller [1960] at a room temperature of $25^{\circ} \mathrm{C}$ and $65 \%$ relative humidity, with a 12-h light-dark cycle. The animals were divided into 8 equal groups. Each group of rats was given separate diet for a period of 8 weeks as follows. Group-1: control group; was given standard died ad-libtum according to the AIN-76 diet [American... 1977]. Group-2: was given $3 \mathrm{~g} / \mathrm{rat} /$ day of dried C-Kariesh cheese coagulated by the YC starter alone, then standard diet ad-libtum. Group-3: was given $3 \mathrm{~g} / \mathrm{rat} / \mathrm{day}$ of dried $\mathrm{C}$-Kariesh cheese coagulated by the YC starter incorporated with rennet, then standard diet ad-libtum. Group-4: was given $3 \mathrm{~g} / \mathrm{rat} /$ day of dried UF-Kariesh cheese coagulated by the YC starter alone, then standard diet ad-libtum. Group-5: was given $3 \mathrm{~g} / \mathrm{rat} / \mathrm{day}$ of dried UF-Kariesh cheese coagulated by the ABT starter alone, then standard diet ad-libtum. Group-6: was given $3 \mathrm{~g} / \mathrm{rat} /$ day of dried UF-Kariesh cheese coagulated by the YC starter incorporated with rennet, then standard diet ad-libtum. Group-7: was given 3 $\mathrm{g} / \mathrm{rat} /$ day of dried UF-Kariesh cheese coagulated by the ABT starter incorporated with rennet, then standard diet ad-libtum. Group-8: was given $3 \mathrm{~g} / \mathrm{rat} / \mathrm{day}$ of dried UF-Kariesh cheese coagulated by GDL alone, then standard diet ad-libtum. Food intake (FI) of each rat was recorded daily. At the end of the $4^{\text {th }}$ week, body weight gain (BWG) and FI were recorded. Food efficiency ratio (FER) for each group was calculated as following: 


$$
\mathrm{FER}=\mathrm{BWG} / \text { total FI }
$$

Before starting the biological experiment and at the end of the $4^{\text {th }}$ week of the experiment, rats were fasted overnight. In the morning, non-heparinized blood samples were obtained from orbital plexus of rat's eye under $\mathrm{CO}_{2}$ anthesia by fine capillary glass tubes in accordance with the method of Schermer [1967], blood samples were allowed to coagulate then centrifuged at $3000 \mathrm{rpm}$ for $6 \mathrm{~min}$ and then serum was removed using a Pasteur pipette into Wassermann tubes and stored at $-40^{\circ} \mathrm{C}$ until being analysed. Blood serum total calcium was determined according to the method of Lehman and Henry [1984]. Ionized calcium was calculated as described by Sava et al. [2005]. Blood serum triglycerides (TG), total cholesterol (TC) and high density lipoprotein (HDL) concentration were determined according to the instruction of manufacturer of assay kits (Sigma Chemical Co, St Louis, MO, USA) according to Friedewald's formula [Friedewald et al. 1972]. Very low density lipoprotein (VLDL) and LDL were calculated as:

$$
\begin{gathered}
\text { VLDL cholesterol }=\mathrm{TG} / 5 \text { and } \mathrm{LDL} \text { cholesterol }= \\
\mathrm{TC}-(\mathrm{VLDL}+\mathrm{HDL} \text { cholesterol }) .
\end{gathered}
$$

The gastrointestinal lactic acid bacteria of feces before starting the study and at the end of the $4^{\text {th }}$ week of the experiment period were collected then counted on Elliker's agar medium as described by Elliker et al. [1956], while the coliform was determined according to Nunez [1976] on violet red bile agar medium.

Carcinogen preparation and administration were carried out using 1,2 di-methyl hydrazine (DMH) according to Kumar et al. [2009] with a slight modification as follows: DMH was dissolved in $1.0 \mathrm{mM}$ EDTA just prior to use and the $\mathrm{pH}$ was adjusted to 6.5 with $1 \mathrm{mM} \mathrm{NaOH}$ to ensure the stability of the solution. Rats received subcutaneous injections of DMH (25 mg/kg body weight), once a week for 4 weeks starting from the $4^{\text {th }}$ week of the experimental period. One rat from each group at the end of the $4^{\text {th }}$ week (before the administration of DMH) and another one at the end of the $8^{\text {th }}$ week were sacrificed. After dissecting the rat, the ends of the ascending and descending colon were cut to detach the entire colon from the rat. Then using a syringe fitted with a catheter the colons were flushed out with saline to remove the debris present inside. After thorough checking for free flow of pure saline from one end to the other, the colons of rats were placed group wise on a tissue paper for macroscopical examination and documentation.

The obtained data were exposed to proper statistical analysis according to statistical analyses system user's guide [SAS 1996].

\section{RESULTS AND DISCUSSION}

Chemical composition of Kariesh cheese. Data given in Table 1 reveal that all factors studied led to significant differences in all criteria determined. Where the application of UF technique helped the cheese to keep its moisture compared with that made using the conventional procedure as declared from the dry matter (DM) content. That could be due to the UF process which led to retention of whey proteins into the retentate and hence into the cheese matrix, made without whey drainage. Whey proteins are characterised with their relatively high water holding capacity [Fayed 1986]. The DM content of Kariesh cheese made using YC starter alone possessed the highest level of DM followed by those made using GDL, while those made by ABT obtained the lowest DM content. These differences could be ascribed essentially to the changes occurred as a result of whey drainage applied in the conventional procedure as indicated from the statistical 2-ways interactions. Moreover, the enzymatic coagulation incorporated with the acidic one made the curd to hold more moisture than declared from the statistical analyses which stated that the DM\% of acidic-coagulation cheeses was statistically higher than those made using rennet-acid coagulation.

Concerning the protein content, the results of Table 1 state that, due to the retention of whey protein into the UF-cheese made without whey drainage, its protein content was higher than that of conventional one. Similar observations were reported by Fayed [1986]. The YC-Kariesh cheese was characterised with the highest protein content followed by those of ABT-ones. The GDL-cheese came in the latest order containing the lowest protein content. Moreover, the use of acidic coagulation alone in Kariesh cheese making led to higher obtained protein content than given when the acidic coagulation was applied in incorporation with the enzymatic one. 
Fayed A.E., Farahat A.M., Metwally A.E., Massoud M.S., Emam A.Q., 2014. Health stimulating properties of the most popular soft cheese in Egypt Kariesh made using skimmed milk UF-retentate and probiotics. Acta Sci. Pol., Technol. Aliment. 13(4), $359-373$.

Table 1. Approximate composition of ultrafiltarated Kariesh cheese versus the conventional one as a function of coagulation procedure

\begin{tabular}{|c|c|c|c|c|c|c|c|c|c|c|}
\hline \multirow{5}{*}{$\begin{array}{c}\text { Property } \\
\%\end{array}$} & \multicolumn{10}{|c|}{ Manufacturing procedure } \\
\hline & \multicolumn{4}{|c|}{ conventional } & \multicolumn{6}{|c|}{ ultrafiltration } \\
\hline & \multicolumn{2}{|c|}{$\mathrm{YC}$} & \multicolumn{2}{|c|}{$\mathrm{ABT}$} & \multicolumn{2}{|c|}{$\mathrm{YC}$} & \multicolumn{2}{|c|}{$\mathrm{ABT}$} & \multicolumn{2}{|c|}{ GDL } \\
\hline & & & & & Rennet inc & orporation & & & & \\
\hline & without* & with & without & with & without & with & without & with & without & with \\
\hline Dry matter & $26.77^{\mathrm{c}, \mathrm{a}, \mathrm{a}}$ & $26.94^{\mathrm{c}, \mathrm{b}, \mathrm{a}}$ & $26.20^{\mathrm{a}, \mathrm{b}, \mathrm{a}}$ & $26.00^{\mathrm{c}, \mathrm{b}, \mathrm{a}}$ & $26.00^{\mathrm{c}, \mathrm{b}, \mathrm{b}}$ & $26.00^{\mathrm{a}, \mathrm{a}, \mathrm{b}}$ & $26.00^{\mathrm{a}, \mathrm{a}, \mathrm{b}}$ & $26.00^{\mathrm{a}, \mathrm{b}, \mathrm{b}}$ & $26.00^{\mathrm{b}, \mathrm{a}, \mathrm{b}}$ & $26.00^{\mathrm{b}, \mathrm{b}, \mathrm{b}}$ \\
\hline $\begin{array}{l}\text { Protein } \\
(\mathrm{TN} \cdot 6.38)\end{array}$ & $13.80^{\mathrm{a}, \mathrm{a}, \mathrm{b}}$ & $12.30^{\mathrm{a}, \mathrm{b}, \mathrm{b}}$ & $16.00^{\mathrm{b}, \mathrm{a}, \mathrm{b}}$ & $14.52^{\mathrm{b}, \mathrm{b}, \mathrm{b}}$ & $17.20^{\mathrm{a}, \mathrm{a}, \mathrm{a}}$ & $17.20^{\mathrm{a}, \mathrm{b}, \mathrm{a}}$ & $17.20^{\mathrm{b}, \mathrm{a}, \mathrm{a}}$ & $17.20^{\mathrm{b}, \mathrm{b}, \mathrm{a}}$ & $16.70^{\mathrm{c}, \mathrm{a}, \mathrm{a}}$ & $16.70^{\mathrm{c}, \mathrm{b}, \mathrm{a}}$ \\
\hline Fat & $1.0^{\mathrm{a}, \mathrm{a}, \mathrm{b}}$ & $1.0^{\mathrm{a}, \mathrm{a}, \mathrm{b}}$ & $1.0^{\mathrm{a}, \mathrm{a}, \mathrm{b}}$ & $1.0^{\mathrm{a}, \mathrm{a}, \mathrm{b}}$ & $1.5^{\mathrm{a}, \mathrm{a}, \mathrm{a}}$ & $1.5^{\mathrm{a}, \mathrm{a}, \mathrm{a}}$ & $1.5^{\mathrm{a}, \mathrm{a}, \mathrm{a}}$ & $1.5^{\mathrm{a}, \mathrm{a}, \mathrm{a}}$ & $1.5^{\mathrm{a}, \mathrm{a}, \mathrm{a}}$ & $1.5^{\mathrm{a}, \mathrm{a}, \mathrm{a}}$ \\
\hline Ash & $3.7100^{\mathrm{c}, \mathrm{b}, \mathrm{b}}$ & $3.9031^{\mathrm{c}, \mathrm{a}, \mathrm{b}}$ & $3.8712^{\mathrm{a}, \mathrm{b}, \mathrm{b}}$ & $4.3220^{\mathrm{a}, \mathrm{a}, \mathrm{b}}$ & $4.2012^{\mathrm{c}, \mathrm{b}, \mathrm{a}}$ & $4.2001^{\mathrm{c}, \mathrm{a}, \mathrm{a}}$ & $4.2011^{\mathrm{a}, \mathrm{b}, \mathrm{a}}$ & $4.2050^{\mathrm{a}, \mathrm{a}, \mathrm{a}}$ & $4.3110^{\mathrm{b}, \mathrm{b}, \mathrm{a}}$ & $4.400^{\mathrm{b}, \mathrm{a}, \mathrm{a}}$ \\
\hline $\begin{array}{l}\text { Sodium } \\
\text { chloride }\end{array}$ & $1.95^{\mathrm{a}, \mathrm{a}, \mathrm{a}}$ & $2.07^{\mathrm{a}, \mathrm{a}, \mathrm{a}}$ & $1.96^{\mathrm{a}, \mathrm{a}, \mathrm{a}}$ & $2.13^{\mathrm{a}, \mathrm{a}, \mathrm{a}}$ & $2.00^{\mathrm{a}, \mathrm{a}, \mathrm{a}}$ & $2.00^{\mathrm{a}, \mathrm{a}, \mathrm{a}}$ & $2.00^{\mathrm{a}, \mathrm{a}, \mathrm{a}}$ & $2.00^{\mathrm{a}, \mathrm{a}, \mathrm{a}}$ & $2.00^{\mathrm{a}, \mathrm{a}, \mathrm{a}}$ & $2.00^{\mathrm{a}, \mathrm{a}, \mathrm{a}}$ \\
\hline
\end{tabular}

$\mathrm{YC}$ - yoghurt bacterial starter culture, $\mathrm{ABT}$ - probiotic starter culture, GDL - glucono delta lactone, TN - total nitrogen.

*Control cheese.

The letters before comma possess the factor of source of acidic coagulation, while those after comma possess the factors of incorporation with rennet and manufacturing procedure respectively. The mean with the same letters at any position did not significantly differ $(\mathrm{p}>0.05)$.

Table 2. Titratable acidity (TA) \% and pH values of ultrafiltrated Kariesh cheese versus the conventional one as affected either by the source of acidic coagulation or the incorporation with rennet during storage period

\begin{tabular}{|c|c|c|c|c|c|c|c|c|c|c|c|}
\hline \multirow{4}{*}{$\begin{array}{c}\text { Prop- } \\
\text { erty } \\
\%\end{array}$} & \multirow{4}{*}{$\begin{array}{c}\text { Cold } \\
\text { storage } \\
\text { period } \\
\text { week }\end{array}$} & \multicolumn{10}{|c|}{ Manufacturing procedure } \\
\hline & & \multicolumn{4}{|c|}{ conventional } & \multicolumn{6}{|c|}{ ultrafiltration } \\
\hline & & \multicolumn{2}{|c|}{$\mathrm{YC}$} & \multicolumn{2}{|c|}{$\mathrm{ABT}$} & \multicolumn{2}{|c|}{$\mathrm{YC}$} & \multicolumn{2}{|c|}{$\mathrm{ABT}$} & \multicolumn{2}{|c|}{ GDL } \\
\hline & & without* & with & without & with & without & with & without & with & without & with \\
\hline \multirow[t]{4}{*}{ TA $\%$} & fresh & $0.77^{\mathrm{b}, \mathrm{a}, \mathrm{a}, \mathrm{c}}$ & $0.76^{\mathrm{b}, \mathrm{b}, \mathrm{a}, \mathrm{c}}$ & $0.80^{\mathrm{c}, \mathrm{a}, \mathrm{a}, \mathrm{c}}$ & $0.72^{\mathrm{c}, \mathrm{b}, \mathrm{a}, \mathrm{c}}$ & $0.9^{\mathrm{b}, \mathrm{a}, \mathrm{b}, \mathrm{c}}$ & $0.63^{\mathrm{b}, \mathrm{b}, \mathrm{b}, \mathrm{c}}$ & $0.82^{\mathrm{c}, \mathrm{a}, \mathrm{b}, \mathrm{c}}$ & $0.24^{\mathrm{c}, \mathrm{b}, \mathrm{b}, \mathrm{c}}$ & $1.09^{\mathrm{a}, \mathrm{a}, \mathrm{b}, \mathrm{c}}$ & $0.69^{\mathrm{a}, \mathrm{b}, \mathrm{b}, \mathrm{c}}$ \\
\hline & 2 & $1.01^{\mathrm{b}, \mathrm{a}, \mathrm{a}, \mathrm{b}}$ & $0.82^{\mathrm{b}, \mathrm{b}, \mathrm{a}, \mathrm{b}}$ & $1.11^{\mathrm{c}, \mathrm{a}, \mathrm{a}, \mathrm{b}}$ & $0.86^{\mathrm{c}, \mathrm{b}, \mathrm{a}, \mathrm{b}}$ & $1.06^{\mathrm{b}, \mathrm{a}, \mathrm{b}, \mathrm{b}}$ & $0.68^{\mathrm{b}, \mathrm{b}, \mathrm{b}, \mathrm{b}}$ & $0.93^{\mathrm{c}, \mathrm{a}, \mathrm{b}, \mathrm{b}}$ & $0.50^{\mathrm{c}, \mathrm{b}, \mathrm{b}, \mathrm{b}}$ & $1.15^{\mathrm{a}, \mathrm{a}, \mathrm{b}, \mathrm{b}}$ & $0.70^{\mathrm{a}, \mathrm{b}, \mathrm{b}, \mathrm{b}}$ \\
\hline & 4 & $1.20^{\mathrm{b}, \mathrm{a}, \mathrm{a}, \mathrm{a}}$ & $0.85^{\mathrm{b}, \mathrm{b}, \mathrm{a}, \mathrm{a}}$ & $1.21^{\mathrm{c}, \mathrm{a}, \mathrm{a}, \mathrm{a}}$ & $0.88^{\mathrm{c}, \mathrm{b}, \mathrm{a}, \mathrm{a}}$ & $1.10^{\mathrm{b}, \mathrm{a}, \mathrm{b}, \mathrm{a}}$ & $0.70^{\mathrm{b}, \mathrm{b}, \mathrm{b}, \mathrm{a}}$ & $1.00^{\mathrm{c}, \mathrm{a}, \mathrm{b}, \mathrm{a}}$ & $0.53^{\mathrm{c}, \mathrm{b}, \mathrm{b}, \mathrm{a}}$ & $1.19^{\mathrm{a}, \mathrm{a}, \mathrm{b}, \mathrm{a}}$ & $0.75^{\mathrm{a}, \mathrm{b}, \mathrm{b}, \mathrm{a}}$ \\
\hline & fresh & $4.50^{\mathrm{c}, \mathrm{b}, \mathrm{b}, \mathrm{a}}$ & $4.70^{\mathrm{c}, \mathrm{a}, \mathrm{b}, \mathrm{a}}$ & $4.53^{\mathrm{b}, \mathrm{b}, \mathrm{b}, \mathrm{a}}$ & $4.77^{\mathrm{b}, \mathrm{a}, \mathrm{b}, \mathrm{a}}$ & $5.11^{\mathrm{c}, \mathrm{b}, \mathrm{a}, \mathrm{a}}$ & $5.36^{\mathrm{c}, \mathrm{a}, \mathrm{a}, \mathrm{a}}$ & $5.06^{\mathrm{b}, \mathrm{b}, \mathrm{a}, \mathrm{a}}$ & $5.88^{\mathrm{b}, \mathrm{a}, \mathrm{a}, \mathrm{a}}$ & $5.31^{\mathrm{a}, \mathrm{b}, \mathrm{a}, \mathrm{a}}$ & $5.37^{\mathrm{a}, \mathrm{a}, \mathrm{a}, \mathrm{a}}$ \\
\hline
\end{tabular}

$\mathrm{YC}$ - yoghurt bacterial starter culture, ABT - probiotic starter culture, GDL - glucono delta lactone, TN - total nitrogen.

*Control was made conventionally using cow's skim milk enriched to $13 \%$ dry matter, coagulated by YC bacterial starter culture. The letters before comma possess the factor of source of acidic coagulation, while those after comma possess the factors of incorporation with rennet and manufacturing procedure respectively. The mean with the same letters at any position did not significantly differ $(\mathrm{p}>0.05)$. 
Fayed A.E., Farahat A.M., Metwally A.E., Massoud M.S., Emam A.Q., 2014. Health stimulating properties of the most popular soft cheese in Egypt Kariesh made using skimmed milk UF-retentate and probiotics. Acta Sci. Pol., Technol. Aliment. 13(4), $359-373$.

Regarding the fat content of Kariesh cheese, the statistical analysis confirmed that the differences which occurred due to the manufacture procedure were significant, where the fat content of UF-Kariesh cheese was higher than the conventional one which lost some fat during whey drainage. Neither the source of acidic coagulation, nor the incorporation with rennet had significant effect on the fat content of the resultant Kariesh cheese.

Concerning the ash content, the UF technique led to increase the ash content in cheese, which was in the highest level compared with that of conventional one. These phenomena are in accordance with those reported by Fayed [1986]. Moreover the ash content of Kariesh cheese differed significantly by the source of acidic coagulation, whereas the ABT-cheese possessed the highest ash content followed by GDL-cheese, while that of YC-cheese came in the last order. The depending on the acidic coagulation alone in the cheese making led to obtain Kariesh cheese with ash content lower than when the rennet was used besides the acidic one. That could be due to the fact that the acid produced for milk coagulation led consequently to increase of the level of soluble salts and hence raised their availability loss during the whey drainage step compared with the relatively lower acid produced when the rennet was incorporated with the bacterial starter culture.

Titratable acidity and pH value of Kariesh cheese. As shown in Table 2, the UF-cheese had titratable acidity (TA) $\%$ lower and hence $\mathrm{pH}$ value higher than those of conventional one. That could be attributed to the relatively lower water activity and the bacterial growth suffered in UF-retentate. While the relatively higher $\mathrm{pH}$ value may be due to the considerable high buffering capacity possessed the UF-cheese. These observations are in agreement with those found by Fayed [1986]. The GDL-cheese gained the highest TA $\%$ followed by those of YC- and ABT-cheeses resp. Moreover, the acid produced in Kariesh cheese by the acidic coagulation alone was higher than when it was made by the acidic-enzymatic coagulation system. By prolonging the cold storage period, the TA \% of all cheese was gradually increased until the end of experimental period (4 weeks).

SDS-PAGE electrophoretogram of Kariesh cheese. Regarding the protein pattern, the electrophoretogram given in Figure 3 shows that the band density of all fractions was obviously influenced either by the manufacture procedure (conventional and ultrafiltration) or the coagulation material whether the type of bacterial starter culture or organic acid whether alone or incorporated with the rennet. Where the pattern of UF-Kariesh cheese obtained with the incorporation between $\mathrm{YC}, \mathrm{ABT}$ or GDL and rennet were distinguished with the presence of the glycomacropeptide (GMP) band. That could be due to the retention of this peptide into cheese matrix as a result of the absence of the whey drainage step. The healthy multi functional spectra contributed to this incorporated peptide were reviewed by Fayed [2012]. Whereas several useful biological activities, including binding of cholera toxin and E. coli enterotoxins, inhibiting of bacterial and viral adhesion, suppression of gastric secretions, promotion of bifidobacterial growth and modulation of immune responses. GMP contains no aromatic amino acids and is therefore used for phenyleketonuria suffering patients. On the contrary, this band totally disappeared with regard to those either of the acidic-coagulated UF cheeses or the conventional ones, whether coagulated with the bacterial culture alone or incorporated with rennet. Where the whey drainage step applied in the conventional method the GMP was allowed to drain

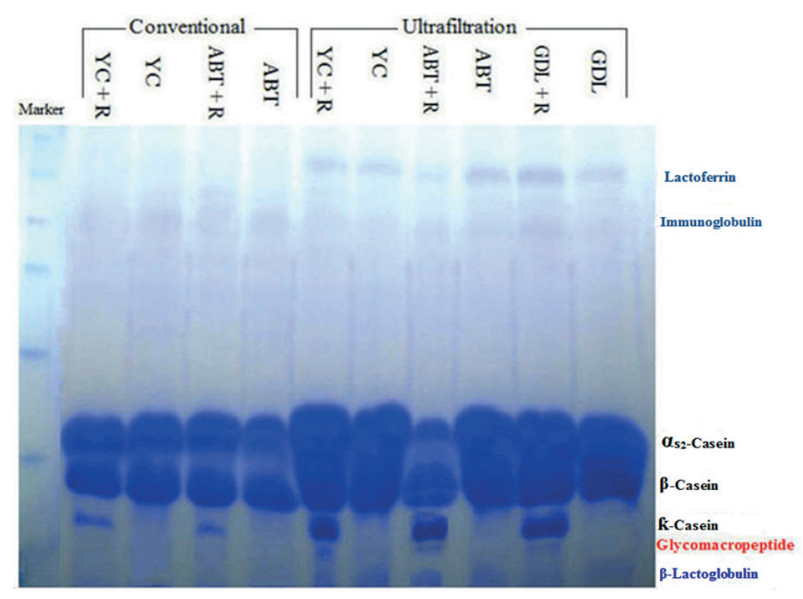

Fig. 3. SDS-PAGE electrophoretogram of ultrafiltrated Kariesh cheese coagulated either by bacterial yoghurt starter culture (YC), probiotic starter culture (A or glucono delta lactone (GDL), whether alone or incorporated with rennet $(\mathrm{R})$ versus the conventional one 
with the whey. Similarly, the UF-cheeses kept the whey proteins un-drained in comparison with the conventional ones which lost most of their whey proteins during the whey drainage step. The obtained results are more or less in accordance with those found by Farrell et al. [2004], and Gab-Allah [2011].

\section{BIOLOGICAL ADVANTAGES OF KARIESH CHEESE}

Food efficiency ratio. Data of Table 3 indicate that although the adjustment of the cheese-feeding quantity at $3 \mathrm{~g} / \mathrm{rat} /$ day, the cheese manufacturing method whether C- or UF-style, as well as the acidic source whether the YC, ABT or even GDL; whether they were separately used or in combination with rennet resulted in significant changes in the consumed amount of the standard diet, which was open available for all rats. Therefore, the obtained parameters reflect the impact of the cheeses type on the total diet eaten. Where, both of FI, BWG and FER were increased in ABT-cheese fed rats followed by those fed on YC and GDL ones respectively, especially when cheeses were made with acid coagulation alone without rennet incorporation. The rats' appetite for eating improved when they consumed UF-cheese versus the conventional one as declared from all feeding parameters calculated, namely, FI, BWG and FER.

\section{BLOOD SERUM PROFILE}

Total and ionized calcium. Results of Table 4 state that the blood serum of rats gained higher total, as well as ionized calcium contents, when rats had been fed on Kariesh cheese cultured with ABT starter culture or acidified with GDL versus those of fed on YC-Kariesh cheeses. The incorporation with rennet had no influence on the two parameters determined. The results confirm also that, the feed on cheeses made without whey drainage, i.e. UF-Kariesh cheese led indeed to increase of the total and ionized calcium concentrations in the blood serum more than when C-Kariesh cheese or standard diet were used. Although the overall changes in the blood serum concentration toward either of total or ionized calcium due to the feed on cheese for 4 weeks were increasingly significant, but the separate difference $\%$ for each group showed that the parameters declined as a result of the feed on
C-cheeses whether made with or without rennet incorporation (groups 2 and 3 ). This phenomenon could be attributed to the whey drainage step applied in the conventional method especially in the acidic phase, where most calcium of acidic cheese curd would be lost within the whey. Therefore the obtained biological data indicated that, the C-Kariesh cheese is not a suitable source of the bio-available calcium versus the UF-one, whose retentate contains total, as well as soluble calcium higher than in raw milk, from which the retentate was obtained.

Lipids and cholesterols. Data given in Table 5 reveal that although the TC levels were not influenced, the levels of the HDLC raised by eating YC-cheeses followed by ABT and GDL-cheeses resp. While the LDLC level was high in the blood serum of rats fed on GDL-cheese followed, in order, by YC and ABT-cheeses. That means, the use of bacterial starter as a source of acid production for cheese making led reduction of the LDL level of blood serum versus that coagulated by adding GDL. Moreover, the incorporation of rennet in Kariesh cheese making led to increase TC and to decrease both HDLC and LDLC levels in the blood serum of rats fed thereon.

Concerning the feeding style, the consumption of C-cheeses lowered the TC and HDLC levels, while the level of LDLC was heightened. On the contrast the feeding on UF-cheese led to reduce the level of

Table 3. Food intake, body weight gain and food efficiency ratio (FER) of rats at the end of feeding period ( 28 days) on dried conventional and ultrafiltrated Kariesh cheese coagulated using different coagulation systems

\begin{tabular}{cccc}
\hline Group & Food intake, $g$ & Body weight gain, g & FER \\
\hline 1 & $340.31 \pm 7.63$ & $60.01 \pm 6.45$ & 0.176 \\
2 & $339.49 \pm 6.18$ & $56.74 \pm 8.02$ & 0.167 \\
3 & $338.98 \pm 8.05$ & $56.01 \pm 7.12$ & 0.165 \\
4 & $339.83 \pm 5.98$ & $57.96 \pm 6.00$ & 0.171 \\
5 & $340.02 \pm 6.73$ & $58.03 \pm 8.11$ & 0.171 \\
6 & $339.05 \pm 6.57$ & $57.83 \pm 6.38$ & 0.171 \\
7 & $339.25 \pm 6.04$ & $58.12 \pm 7.34$ & 0.171 \\
8 & $338.92 \pm 7.11$ & $57.03 \pm 9.01$ & 0.168 \\
\hline
\end{tabular}


Fayed A.E., Farahat A.M., Metwally A.E., Massoud M.S., Emam A.Q., 2014. Health stimulating properties of the most popular soft cheese in Egypt Kariesh made using skimmed milk UF-retentate and probiotics. Acta Sci. Pol., Technol. Aliment. 13(4), $359-373$.

Table 4. Blood serum total calcium and ionized calcium concentrations ( $\mathrm{mg} / \mathrm{dl})$ of rats' at the beginning and end of feeding period ( 28 days) on dried conventional and ultrafiltrated Kariesh cheese coagulated by different system

\begin{tabular}{|c|c|c|c|c|c|}
\hline Groups & $\begin{array}{l}\text { Experimental } \\
\text { period, week }\end{array}$ & Total calcium & $\%$ difference & Ionized calcium & $\%$ difference \\
\hline \multirow[t]{2}{*}{1} & 0 & $8.90 \pm 0.60$ & 0.11 & $4.65 \pm 0.058$ & 0.00 \\
\hline & 4 & $8.91 \pm 0.33$ & & $4.65 \pm 0.052$ & \\
\hline \multirow[t]{2}{*}{2} & 0 & $8.92 \pm 0.20$ & -7.40 & $4.66 \pm 0.053$ & -1.50 \\
\hline & 4 & $8.26 \pm 0.42$ & & $4.59 \pm 0.061$ & \\
\hline \multirow[t]{2}{*}{3} & 0 & $8.91 \pm 0.34$ & -6.06 & $4.64 \pm 0.048$ & -0.43 \\
\hline & 4 & $8.37 \pm 0.58$ & & $4.62 \pm 0.056$ & \\
\hline \multirow[t]{2}{*}{4} & 0 & $8.89 \pm 0.56$ & 7.09 & $4.64 \pm 0.053$ & 1.51 \\
\hline & 4 & $9.52 \pm 0.62$ & & $4.71 \pm 0.060$ & \\
\hline \multirow[t]{2}{*}{5} & 0 & $8.89 \pm 0.24$ & 8.32 & $4.63 \pm 0.040$ & 1.94 \\
\hline & 4 & $9.63 \pm 0.52$ & & $4.72 \pm 0.056$ & \\
\hline \multirow[t]{2}{*}{6} & 0 & $8.90 \pm 0.34$ & 5.28 & $4.63 \pm 0.063$ & 1.30 \\
\hline & 4 & $9.37 \pm 0.53$ & & $4.69 \pm 0.051$ & \\
\hline \multirow[t]{2}{*}{7} & 0 & $8.90 \pm 0.29$ & 3.93 & $4.64 \pm 0.049$ & 0.86 \\
\hline & 4 & $9.25 \pm 0.60$ & & $4.68 \pm 0.057$ & \\
\hline \multirow[t]{2}{*}{8} & 0 & $8.90 \pm 0.49$ & 5.73 & $4.64 \pm 0.055$ & 1.29 \\
\hline & 4 & $9.41 \pm 0.42$ & & $4.70 \pm 0.040$ & \\
\hline
\end{tabular}

Table 5. Lipid profiles ( $\mathrm{mg} / \mathrm{dl})$ of rats' blood serum at the beginning and end of feeding period (28 days) on dried conventional and ultrafiltrated Kariesh cheese coagulated by different systems

\begin{tabular}{|c|c|c|c|c|c|c|c|c|c|}
\hline Groups & $\begin{array}{l}\text { Experimental } \\
\text { period, week }\end{array}$ & Triglycerides & $\begin{array}{c}\% \\
\text { difference }\end{array}$ & $\begin{array}{c}\text { Total } \\
\text { cholesterol }\end{array}$ & $\begin{array}{c}\% \\
\text { difference } \\
\end{array}$ & $\begin{array}{c}\text { HDL } \\
\text { cholesterol }\end{array}$ & $\begin{array}{c}\% \\
\text { difference }\end{array}$ & $\begin{array}{c}\text { LDL } \\
\text { cholesterol }\end{array}$ & $\begin{array}{c}\% \\
\text { difference } \\
\end{array}$ \\
\hline \multirow[t]{2}{*}{1} & 0 & $85.32 \pm 2.56$ & 1.59 & $72.91 \pm 2.79$ & 1.74 & $21.65 \pm 0.80$ & 9.61 & $32.19 \pm 0.96$ & 5.68 \\
\hline & 4 & $86.68 \pm 2.03$ & & $74.18 \pm 2.18$ & & $23.73 \pm 1.21$ & & $34.02 \pm 1.35$ & \\
\hline \multirow[t]{2}{*}{2} & 0 & $83.24 \pm 4.15$ & 1.42 & $73.55 \pm 3.52$ & 1.63 & $21.79 \pm 1.07$ & 7.71 & $33.65 \pm 1.27$ & 4.70 \\
\hline & 4 & $84.42 \pm 3.86$ & & $74.75 \pm 1.57$ & & $23.47 \pm 1.92$ & & $35.23 \pm 1.53$ & \\
\hline \multirow[t]{2}{*}{3} & 0 & $84.05 \pm 3.01$ & 1.43 & $71.04 \pm 2.06$ & 1.73 & $21.22 \pm 1.86$ & 8.11 & $33.00 \pm 1.02$ & 4.88 \\
\hline & 4 & $85.25 \pm 4.22$ & & $72.27 \pm 2.95$ & & $22.94 \pm 2.19$ & & $34.61 \pm 1.43$ & \\
\hline \multirow[t]{2}{*}{4} & 0 & $86.65 \pm 4.06$ & 0.92 & $73.11 \pm 3.08$ & 1.33 & $22.61 \pm 2.00$ & 7.83 & $32.87 \pm 1.56$ & 3.13 \\
\hline & 4 & $87.45 \pm 2.16$ & & $74.08 \pm 1.36$ & & $24.38 \pm 0.84$ & & $33.90 \pm 0.99$ & \\
\hline \multirow[t]{2}{*}{5} & 0 & $83.87 \pm 3.18$ & 0.83 & $73.02 \pm 1.90$ & 1.23 & $21.80 \pm 2.57$ & 7.89 & $33.73 \pm 1.49$ & 2.85 \\
\hline & 4 & $84.57 \pm 4.01$ & & $73.92 \pm 2.25$ & & $23.52 \pm 2.10$ & & $34.69 \pm 1.42$ & \\
\hline \multirow[t]{2}{*}{6} & 0 & $84.00 \pm 3.94$ & 1.20 & $72.94 \pm 3.01$ & 1.55 & $22.03 \pm 1.84$ & 9.40 & $33.01 \pm 1.19$ & 3.67 \\
\hline & 4 & $85.01 \pm 2.11$ & & $74.07 \pm 2.54$ & & $24.10 \pm 1.92$ & & $34.22 \pm 1.30$ & \\
\hline \multirow[t]{2}{*}{7} & 0 & $85.55 \pm 3.75$ & 1.05 & $72.03 \pm 2.93$ & 1.42 & $21.52 \pm 2.45$ & 8.60 & $31.79 \pm 1.51$ & 3.33 \\
\hline & 4 & $86.45 \pm 2.83$ & & $73.05 \pm 2.08$ & & $23.37 \pm 2.11$ & & $32.85 \pm 1.34$ & \\
\hline \multirow[t]{2}{*}{8} & 0 & $84.24 \pm 3.01$ & 1.45 & $71.23 \pm 1.89$ & 1.73 & $21.67 \pm 0.98$ & 7.89 & $33.41 \pm 0.95$ & 4.79 \\
\hline & 4 & $85.46 \pm 3.24$ & & $72.46 \pm 2.12$ & & $23.38 \pm 1.87$ & & $35.01 \pm 0.98$ & \\
\hline
\end{tabular}


LDLC versus the C-one. That could be ascribed to the presence of whey proteins trapped into the former as a function of the UF-retention.

Nevertheless, all levels either of TC, HDLC or LDLC were increased in all experimental rats by feeding on all treatments involving the standard diet for 4 weeks.

\section{Gastrointestinal flora}

As noticed from the data of Table 6, fecal flora population, which reflected the feeding situation of rats, revealed that, the utilization of starter cultures in cheese making led to a significant decrease in the rats' gastrointestinal coliform counts than the administration of GDL instead of the bacterial starter cultures. Where, the ABT-cheeses caused the highest reduction in coliform followed by the $\mathrm{YC}$-cheeses than the
GDL-ones. That was clearly due to the relatively higher ability of ABT starter culture to still viable and continue growing to cause the antagonistic effect against the coliform group through the rat's digestive tract. This phenomenon was demonstrated by the higher counts of gastrointestinal LAB noticed when feeding on the ABT-cheeses than those resulted from feeding on each of YC or GDL-cheeses resp. These observations are in agreement with those found by Yuguchi and Okonogi [1992] and Fayed et al. [2011 a and b], who demonstrated that the administration of bifidobacteria to rats increased their number in the intestine, and on the other hand, the numbers of staphylococci and coliform bacteria were significantly reduced in groups received cultured milks as compared to the control. Also Amann et al. [1998] reported that the consumption of bifidobacteria by human would increase colonic

Table 6. Coliform and lactic acid bacteria counts of rats' feces (log cfu/g feces) at the beginning and end of feeding period (28 days) on dried conventional and ultrafiltrated Kariesh cheese coagulated by different systems

\begin{tabular}{|c|c|c|c|c|c|}
\hline Groups & $\begin{array}{l}\text { Experimental } \\
\text { period, week }\end{array}$ & Coliform & LAB & LAB/Coliform & $\%$ difference \\
\hline \multirow[t]{2}{*}{1} & 0 & $5.97 \pm 0.27$ & $7.59 \pm 0.11$ & 41.534 & 2.45 \\
\hline & 4 & $5.97 \pm 0.31$ & $7.60 \pm 0.21$ & 42.553 & \\
\hline \multirow[t]{2}{*}{2} & 0 & $5.96 \pm 0.90$ & $7.61 \pm 0.28$ & 45.055 & 11.45 \\
\hline & 4 & $5.97 \pm 0.13$ & $7.67 \pm 0.21$ & 50.214 & \\
\hline \multirow[t]{2}{*}{3} & 0 & $5.95 \pm 0.42$ & $7.59 \pm 0.11$ & 43.333 & 10.71 \\
\hline & 4 & $5.97 \pm 0.22$ & $7.65 \pm 0.32$ & 47.974 & \\
\hline \multirow[t]{2}{*}{4} & 0 & $5.97 \pm 0.27$ & $7.64 \pm 0.44$ & 46.965 & 56.84 \\
\hline & 4 & $5.91 \pm 0.38$ & $7.78 \pm 0.10$ & 73.659 & \\
\hline \multirow[t]{2}{*}{5} & 0 & $5.96 \pm 0.14$ & $7.62 \pm 0.22$ & 45.792 & 66.51 \\
\hline & 4 & $5.90 \pm 0.03$ & $7.79 \pm 0.53$ & 76.250 & \\
\hline \multirow[t]{2}{*}{6} & 0 & $5.97 \pm 0.41$ & $7.64 \pm 0.85$ & 46.178 & 18.16 \\
\hline & 4 & $5.96 \pm 0.38$ & $7.70 \pm 0.07$ & 54.565 & \\
\hline \multirow[t]{2}{*}{7} & 0 & $5.97 \pm 0.94$ & $7.61 \pm 0.28$ & 43.991 & 26.29 \\
\hline & 4 & $5.95 \pm 0.42$ & $7.70 \pm 0.90$ & 55.556 & \\
\hline \multirow[t]{2}{*}{8} & 0 & $5.97 \pm 0.27$ & $7.59 \pm 0.11$ & 41.534 & 2.45 \\
\hline & 4 & $5.97 \pm 0.31$ & $7.60 \pm 0.21$ & 42.553 & \\
\hline
\end{tabular}


bifidobacteria count. Likewise, Kheadr et al. [2000] found that the use of a mixture of yoghurt and probiotic strains reduced the growth of enterococci and coliform in the intestinal tract.

The results also prove that depending on the starter culture alone in the cheeses making led to a higher reduction in the counts of gastrointestinal coliform than when the starter culture was used besides the rennet, that may be due to the higher initial $\mathrm{LAB}$ count in the acidic coagulated cheeses than those of the acidic-enzymatic cheeses. These results were confirmed by the highest $\mathrm{LAB} /$ coliform ratio found after 28 days of feeding on dried ultrafiltrated cheese coagulated by the ABT starter alone (group-5). Where, the highest difference \% in LAB/coliform between the beginning and end of the feeding period was noticed in group-5.

The gastrointestinal LAB of rats differed significantly by the cheeses manufacturing procedure as declared from the statistical analysis which stated that, the UF-procedure led to obtain a higher gastrointestinal LAB than the conventional one. That could be ascribed to the higher counts of LAB in the UF-cheese as a result of their relatively slow growth in the retentate as well as the presence of whey proteins in the cheese matrix which acted as a growth factor for LAB as reported by Loh and Maznah (1999) and Fayed [2012]. Also, it could be observed that, the gastrointestinal LAB increased by prolonging the feeding period opposite to that done by the coliform, which showed decreases correlated significantly to the increase in LAB in all groups except those fed either on the standard diet or the GDL-cheese.

The colonic persistence against tumor. The photomacrographs present in Figures 4-7 showed that, most of rats fed on the C- and UF-cheeses as well as the standard died throughout the first 4 weeks of the study (before the administration of DMH) possessed a normal colonic architecture. The colons of rats fed on dried UF-Kariesh cheese coagulated by bacterial starter culture alone (whether $\mathrm{YC}$ or $\mathrm{ABT}$ ) reflected a healthier sight before the administration of $\mathrm{DMH}$ than the colons of other groups.

It appeared also that, all rats of each group revealed the presence of colonic tumors after 4 weeks of DMH injection, but there was a significant difference in the number and volume of tumors that occurred, where rats of 1st group, fed on the standard diet, had the highest amount of tumors, those tumors were characterised by their intensive proliferation along the entire colon length. The rats of 2nd and 3rd group, fed on dried C-Kariesh cheeses coagulated by YC starter culture alone or incorporated with rennet, reflected lower incidence of colonic tumors than it happened in 1st group.

The colons of rats of 6th and 7th group, fed on dried UF-cheeses coagulated by YC or ABT starter incorporated with rennet, showed a significant resistance to the colonic tumors incidence. Group 4, fed on dried UF-Kariesh cheese coagulated by YC starter alone, showed the smallest amount of macroscopically visible colonic tumors. There were absolutely non macroscopically visible tumors in the colon of rats fed on dried UF-Kariesh cheese coagulated by the ABT starter culture alone, although there were very few and mild polyps in the colon, these polyps were indicated by the cross marked arrows in Figure 7 as declared in the Figure of the 5th group which fed on dried UF-cheese coagulated by ABT starter alone. Whereas, the feeding on UF-ABT-cheese before and during the injection with $\mathrm{DMH}$ made the colon to be resistant to tumor. That could be ascribed to the highest count of probiotics survived in their colons, which performed with the entrapped whey proteins by the UF process a significant role in preventing the colonic cancer by alteration of metabolic activities of the intestinal microflora, change the physicochemical conditions in the colon, elevating the rat's immune response, production of anticarcinogenic compounds and binding of potential carcinogens. It is worth to mention that the whey proteins entrapped in this cheese acted a synergistic effect with the probiotics for preventing the colonic cancer. These results are in agreement with those obtained by Fodiatis et al. [2008]. The colons of rats of Group 8 which fed on UF-Kariesh cheese coagulated by GDL reflected incidence of a non intensive tumor besides many mild polyps. That could by attributed to altering the tumor's prevalence by the action of the whey proteins entrapped into the cheese matrix. Similar observation was obtained by Hakkak et al. [2001] who suggested that consumption of whey protein-containing diets may reduce the risk of developing colon tumors. 
Fayed A.E., Farahat A.M., Metwally A.E., Massoud M.S., Emam A.Q., 2014. Health stimulating properties of the most popular soft cheese in Egypt Kariesh made using skimmed milk UF-retentate and probiotics. Acta Sci. Pol., Technol. Aliment. 13(4), $359-373$.

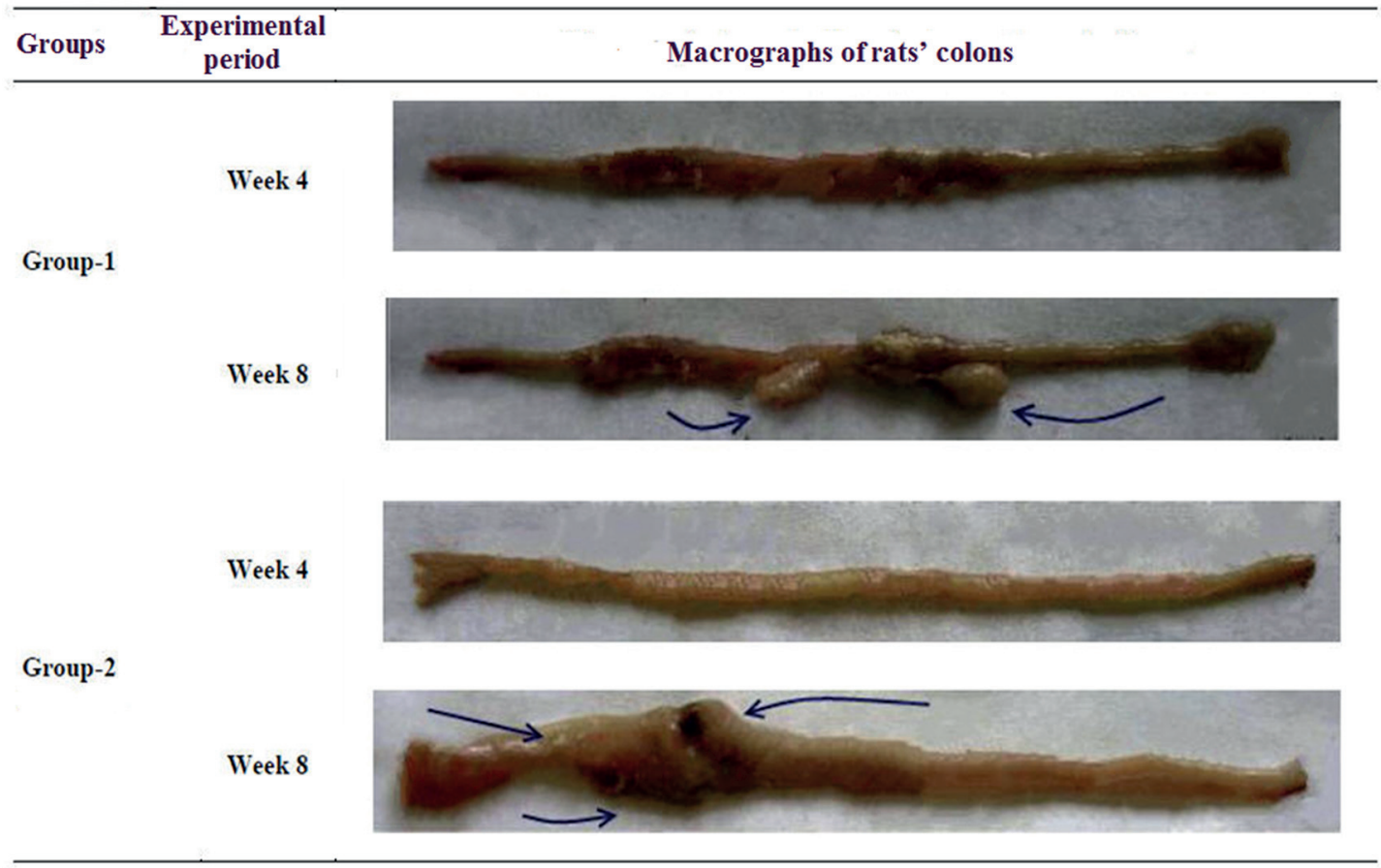

Fig. 4. Macroscopical examination of rats' colon tumor incidence in group 1 and 2 as affected by the diet, experiment period and the injection of the carcinogen

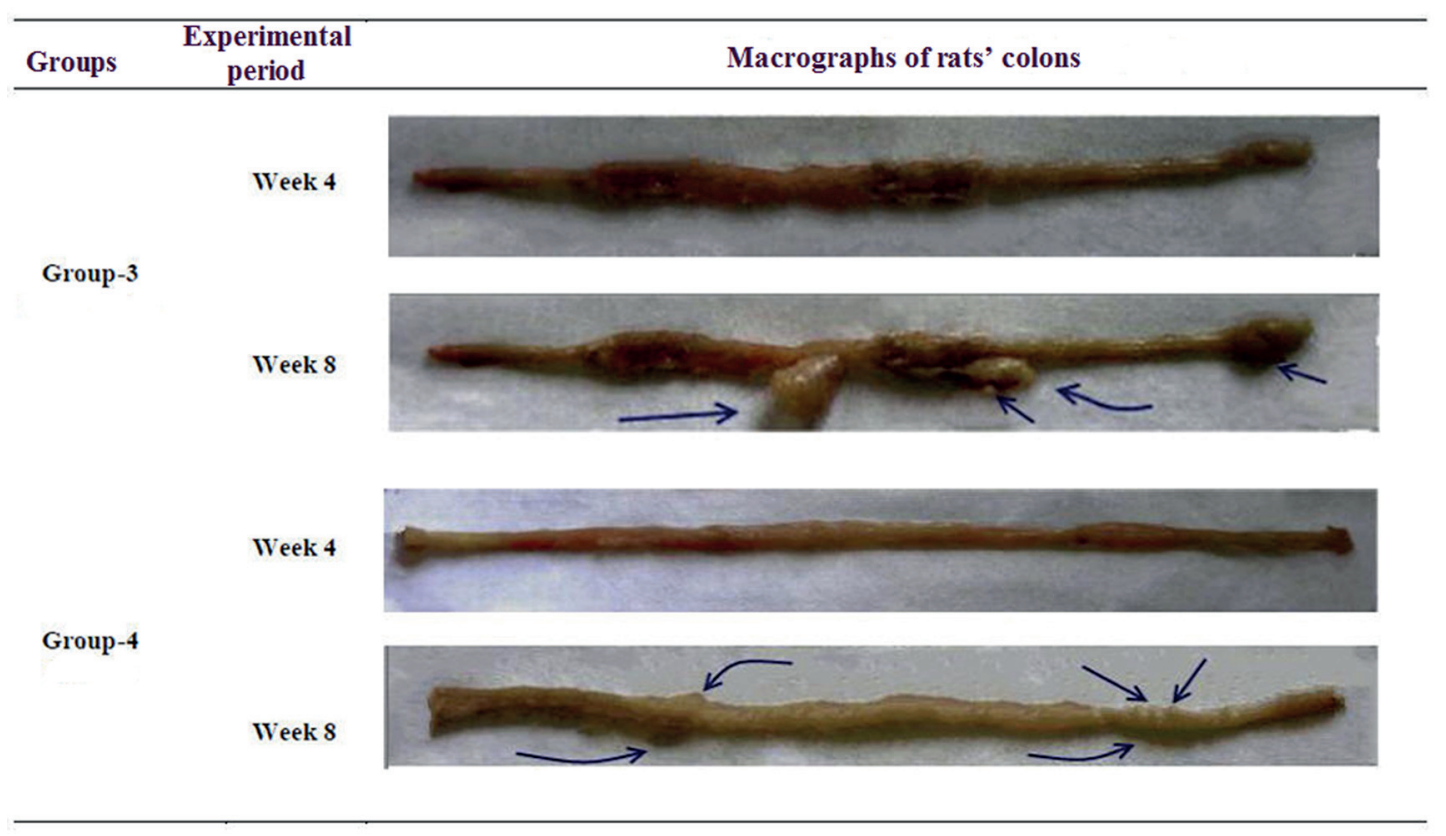

Fig. 5. Macroscopical examination of rats' colon tumor incidence in group 3 and 4 as affected by the diet, experiment period and the injection of the carcinogen 
Fayed A.E., Farahat A.M., Metwally A.E., Massoud M.S., Emam A.Q., 2014. Health stimulating properties of the most popular soft cheese in Egypt Kariesh made using skimmed milk UF-retentate and probiotics. Acta Sci. Pol., Technol. Aliment. 13(4), 359-373.

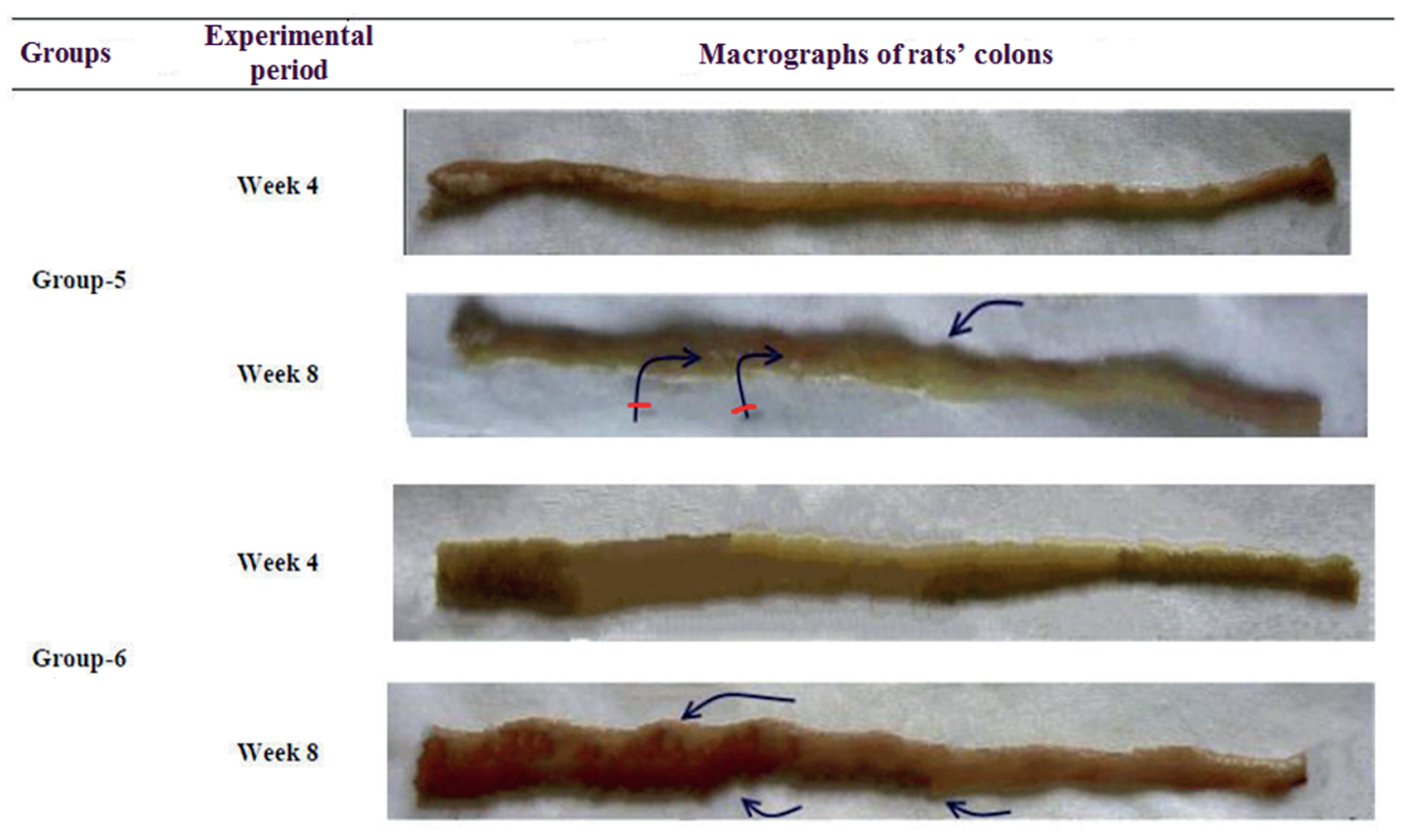

Fig. 6. Macroscopical examination of rats' colon tumor incidence in group 5 and 6 as affected by the diet, experiment period and the injection of the carcinogen

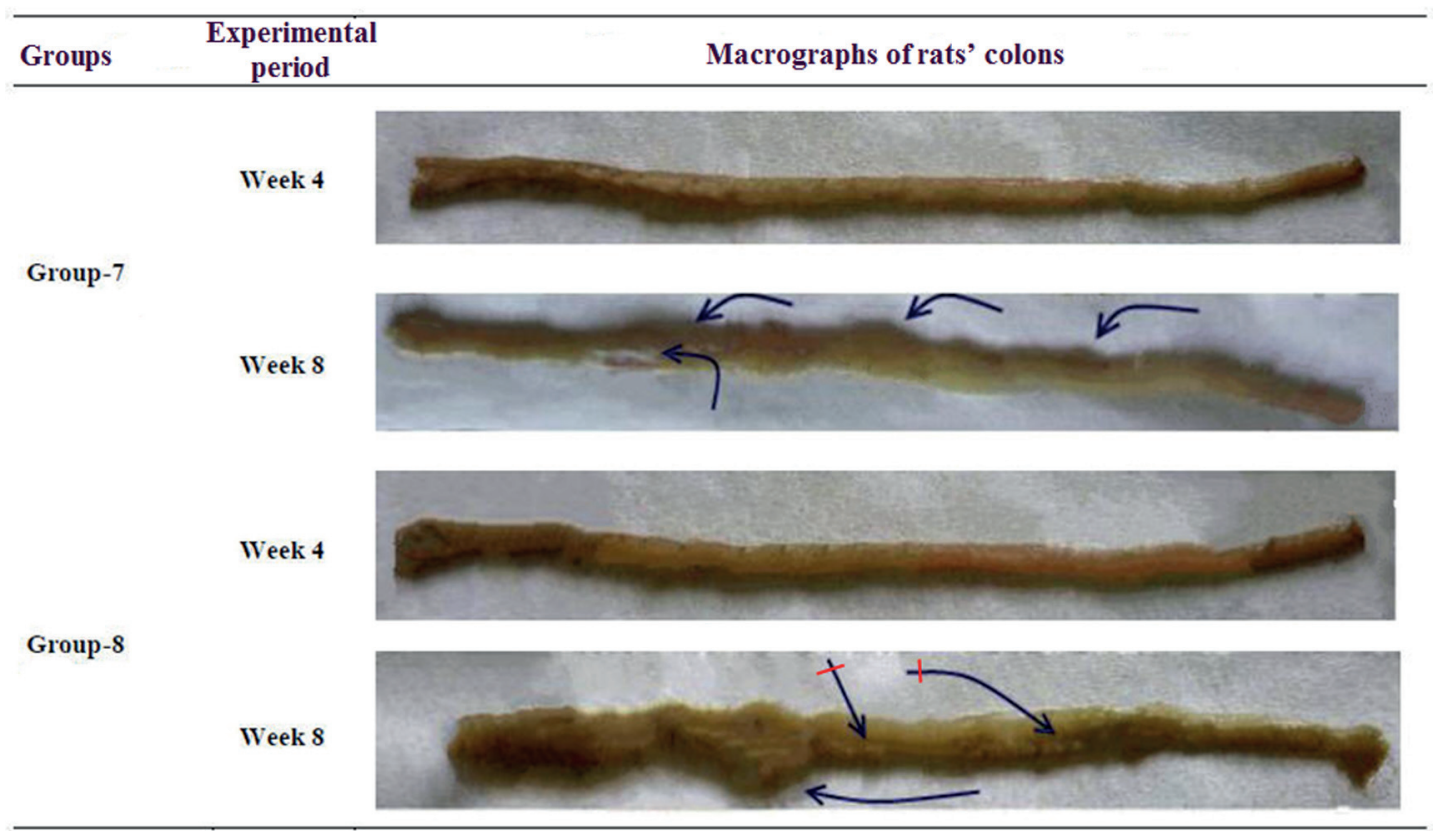

Fig. 7. Macroscopical examination of rats' colon tumor incidence in group 7 and 8 as affected by the diet, experiment period and the injection of the carcinogen 


\section{CONCLUSION}

Finally, the foregoing results led to conclude that Kariesh cheese made without whey drainage using skimmed milk concentrated by UF-process, cultured with the probiotic strains and incorporated renneted, possessed super marketing and physiological advantages. The whey proteins entrapped in this cheese acted a synergistic effect with the probiotics preventing the colonic cancer.

\section{REFERENCES}

Abd El-Salam M.H., El-Shibiny S., El-Alamy H.A., 1984. Production of skimmilk (Kariesh cheese) from ultrafiltrated reconstituted milk. Egypt. J. Dairy Sci. 12, 111-115.

Abdou S.M., Dawood A.H., 1977. Effect of heat treatment of skimmilk on yield, quality and chemical composition of skimmilk cheese (Kariesh). Egypt. J. Dairy Sci. 5, 1-5.

Abou-Dawood A.E., Gomai A.Y., 1977. The use of high total solids reconstituted skimmilk in Kariesh cheese making. Egypt. J. Dairy Sci. 5, 229-234.

Abou-Donia S.A., 1984. Egyptian fresh fermented milk products. New Zeal. J. Dairy Sci. Technol. 19, 7-18.

Abou-Donia S.A., 1991. Manufacture of Egyptian soft pickled cheese. In: Feta and related cheeses. Eds R.K. Robinson, A.Y. Tamime. Ellis Horwood London.

Abou-Donia S.A., 1995. Contribution concerning colour guide of Egyptian cheese varietie. In: A colour guide to cheese and fermented milks. Ed. P.K. Robinson. Champan and Hall London.

Abou-Donia S.A., 1999 a. Geographical distribution and historical development of ancient Egyptian dairy products. Egypt. J. Dairy Sci. 27, 359-368.

Abou-Donia S.A., 1999 b. Importance of fermented milks and related cheese in the Egyptian diet. In: Proceedings the Alexandria Symposium on Starter Cultures and their Use in Dairy Industry. Alexandria, November, 108-114.

Abou-Donia S.A., 2008. Origin, history and manufacturing process of Egyptian dairy products: An overview Alex. J. Food Sci. Technol. 5, 51-62.

Amann M.M., Kullen M.J., Martini M.C., Busta F.F., Brady L.J., 1998. Consumption of exogenous bifidobacteria does not alter fecal bifidobacteria and breathe hydrogen secretion in humans. J. Nutr. 128, 996-1002.

American Institute of Nutrition (AIN) report of the AIN ad hoc committee on standards for nutritional studies. 1977. J. Nutr. 107, 1340-1348.

AOAC, 2007. Association of Official Analytical Chemists. Official method of analysis. Benjamin Franklin Station Washington, USA, 302-850.
Basch J.J., Greenberg R., Farrell H.M.J., 1985. Identification of the milk fat globule proteins. II. Isolation of major proteins from electrophoretic gels and comparison of their amino acid compositions. Biochim. Biophys. Acta 830, 127-35.

El-Gendy S.M., 1983. Fermented foods of Egypt and the middle East. J. Food Prot. 46, 358-367.

EL-Sadek G.M., Abd El-Motaleb L., 1958 a. Effect of heat treatment of milk on the yield, quality and certain properties of standardized separated milk cheese. J. Dairy Res. 25, 85-91.

EL-Sadek G.M., Abd El-Motaleb L., 1958 b. The effect of heat treatment and temperature of storage on the yield, quality and chemical composition of Kariesh cheese. J. Dairy Res. 25, 480-485.

El-Shibiny S., El-Salam M.H., Mahfouz M.B., El-Alamy H.A., 1984. Effect of coagulation method on composition and quality of skimmilk (Karish) cheese made by ultrafiltration technique. Egypt. J. Dairy Sci. 12, 243-250.

El-Zayat A.I., Omar M.M., 1987. Kareish cheese prepared from ultrafiltered milk. J. Dairy Res. 54, 545-550.

Elliker P., Anderson A., Hannesson G., 1956. An agar culture medium for lactic acid streptococci and lactobacilli. J. Dairy Sci. 39, 1611-1956.

Fahmi A.H., 1950. Studies on Kareish cheese. Ph.D. Thesis. Univ. Reading England.

Farrell H.M., Jimenez-Flores J., Bleck R.G., Brown E.M., Butler J.E., Creamer L.K., Hicks C.L., Hollar C.M., Ng-Kwai-Hang K.F., Swaisgood H.E., 2004. Nomenclature of the proteins of cows' milk-sixth revision. J. Dairy Sci. 87, 1641-1674.

Fayed A.E., 1986. Protein fortification of some dairy products. Ph.D. Thesis, Food Sci. Dept. Fac. Agric. Ain Shams Univ. Cairo, Egypt, 139-143.

Fayed A.E., 2012. Healthy spectra of milk glycoproteins and their fragments - a review article. Pol. J. Food Nutr. Sci. 62, 125-142.

Fayed A.E., Hussein G.A., El-Mahdy L.D., Masoud M.S., Gab-Allah R.H., 2011 a. Glycoprotein fortification of bioyoghurt. Egypt. J. Food Sci. 39, 81-106.

Fayed A.E., Hussein G.A., Youssef M.S., Gab-Allah R.H., 2011 b. Improvement of yoghurt efficiency as functional food by glycoprotein fortification. J. Biol. Chem. Environ. Sci. 6, 241-265.

Friedewald W.T., Levy R.I., Fredrickson D.S., 1972. Estimation of the concentration of low-density lipoprotein cholesterol in plasma, without use of the preparative ultracentrifuge. Clin. Chem. 18, 499-502.

Fodiatis C.I., Stoidis N.C.H., Spyropoulos B.G., Zografos D.E., 2008. Role of probiotics, prebiotics and synbiotics in chemoprevention for colorectal cancer. World J. Gastroenterol. 14, 6453-6457. 
Fayed A.E., Farahat A.M., Metwally A.E., Massoud M.S., Emam A.Q., 2014. Health stimulating properties of the most popular soft cheese in Egypt Kariesh made using skimmed milk UF-retentate and probiotics. Acta Sci. Pol., Technol. Aliment. 13(4), 359-373.

Gab-Allah R.H., 2011. Studies on improvement of yoghurt efficiency as a functional food. Ph.D. Thesis, Food Sci. Dept., Fac. Agric., Ain Shams Univ. Cairo, Egypt.

Hakkak R., Korourian S., Ronis M.J., Badger T.M., 2001. Dietary whey protein protects against azoxymethane-induced colon tumors in male rats. Cancer Epidem. Biomar. Prev. 10, 555-558.

Hamdy A.M., Sayed S.A., 1971. Effect of citric acid on some properties of Kariesh cheese. Agric. Res. Rev. 49, 191-195.

Hassan A.N., Corredig M., Frank J.F., Elsoda M., 2004. Microstructure and rheology of an acid-coagulated cheese (Karish) made with an exopolysaccharide - producing Streptococcus thermophilus strain and its exopolysaccharide non-producing genetic variant. J. Dairy Res. 71: 116-120.

Hegazy N.M., Nasr M.M., Fayed A.E., Youssef M.S., 2012. Economics scale for processing of white soft cheese in Egypt. Egypt. J. Agric. Econ. 21, 1079-1094.

Hofi A.A., Renner E., Fayed A.E., 1986. Effect of some skimmilk powder reconstitution ratio's on the characters of UF-Kariesh cheese. In: Proc. 3rd Egypt. Conf. Dairy Sci. Technol., Cairo, November, 33-34.

Hofi M.A., Ali H.M., Heikal Y.A., El-Beialy A.R., 2004. Microstructure and rheological properties of ultrafiltered Kariesh cheese made by direct acidification. In: Proc. 9th Egypt. Conf. Dairy Sci. Technol., October, 419-443.

Kheadr E.E., Abd Rahman A.M., El-Soukary F.A., 2000. Impact of Zabady and probiotic strains on serum cholesterol and lipoprotein profile in rats. Alex. J. Agric. Res. 45, 81-93.

Kotterer R., Munch S., 1978. Untersuchungsverfahren fuer das Milcwirtschaftliche Laboratorium. Volkswirtschaftliche Munchen.

Kumar V., Vennila S., Nalini N., 2009. Modifying effects of morin on the development of aberrant crypt foci and bacterial enzymes in experimental colon cancer. Food Chem. Toxicol. 47, 309-315.

Laemmli U.K., 1970. Cleavage of structural proteins during the assembly of the head of bacteriophage T4. Nature $227,680-685$

Lehman H.P., Henry J.B., 1984. Calcium determination. In: Clinical diagnosis and management by laboratory methods. Ed. J.B. Henry. Saunders Philadelphia, 1431-1438.

Received - Przyjęto: 2.04.2014

For citation - Do cytowania
Mahran G.A., Hagrass A.E., Renner E., Fayed A.E., 1986. Comparison between the ultrafiltration and traditional kariesh cheeses produced from fresh and dried skimmilk. In: Proc. 3rd Egypt. Conf. Dairy Sci. Technol. Cairo, November, 33.

Loh S.J., Maznah I., 1999. The effect of different milks and milk proteins on the growth of Bifidobacterium infantis ATCC 27920 in vitro. Malays J. Nutr. 5, 61-70.

Maubois J.L., Pierre A., Fauquant J., Piot M., 1987. Industrial fractionation of main whey proteins. Int. Dairy Fed. Bull. 212, 154-159.

Nunez M., 1976. Microbial flora of Manchego cheese. VI. Pediococci. Anim. Inst. Nac. Invest. Agrar., Gen. No. 4,75 (Dairy Sci. Abstr. 1978, 458).

Renner J.E., Abd El-Salam M.H., 1991. Application of ultrafiltration in the dairy industry. Elsevier London.

Sava L., Pillai S., More U., Sontakke A., 2005. Serum calcium measurement: Total versus free (ionized) calcium. Indian J. Clin. Biochem. 20, 158-161.

SAS, 1996. Statistical Analysis System. SAS user's guide. Statistics. SAS Inst. Cary, NC, U.S.A.

Schermer S., 1967. The blood morphology of laboratory animals. Lengmans and Green Philadelphia, USA.

Schiller K., 1960. Ein Stoffwechselkafig fuer Ratten. Z. Tierphysiol. Tierer. 15, 305-308.

Shamsia S.M., El-Ghannam S.M., 2012. Manufacture of Labneh from cow's milk using ultrafiltration retentate with or without addition of permeate concentrate. J. Anim. Prod. Adv. 2, 166-173.

Studier F.W., 1973. Analysis of bacteriophage T7 early RNAs and proteins on slab gels. J. Mol. Biol. 79, 237-248.

Wahba A., El-Abbassy F., 1982. Manufacture of Kareish cheese without starter I. The use of lactic, acetic and hydrochloric acids. Egypt. J. Dairy Sci. 10 (1), 61-65.

Weber K., Osborn M., 1969. The reliability of molecular weight determinations by dodecyl sulfate-polyacrylamide gel electrophoresis. J. Biol. Chem. 244, 4406-4412.

Youssef A.M., Salama F.A., Salam A.E., 1981. Effect of some technological factors on the manufacture of Kariesh cheese from reconstituted skimmilk. Egypt. J. Dairy Sci. 9, 171-180.

Yuguchi H.T., Okonogi S., 1992. Fermented milks, lactic drinks and intestinal microflora. In: Function of fermented milk. Eds Y. Nakazawam, A. Hosono. Elsevier App. Sci. London, UK, 248-249.

Accepted for print - Zaakceptowano do druku: 9.07.2014

Fayed A.E., Farahat A.M., Metwally A.E., Massoud M.S., Emam A.Q., 2014. Health stimulating properties of the most popular soft cheese in Egypt Kariesh made using skimmed milk UF-retentate and probiotics. Acta Sci. Pol., Technol. Aliment. 13(4), 359-373. 